\title{
Die kulturele en praktiese waarde van inheemse kennis oor plantgebruike in die 21ste eeu
}

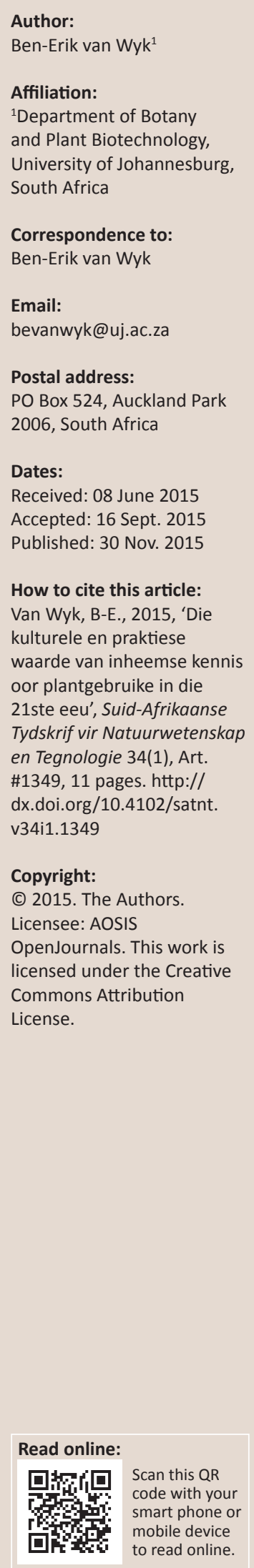

Kritici van etnobotaniese navorsing kan moontlik die vraag vra wat die relevansie daarvan is om die inheemse kennis rondom plantgebruike van verskillende kultuurgroepe op te teken. Hierdie artikel fokus op die waarde en voordele van etnobotaniese studies in die 21ste eeu. Die konteks is kwantitatiewe etnobotaniese opnames wat die afgelope klompie jare in SuidAfrika gedoen is. Vir die bespreking van die Matriksmetode, wat deur Van Wyk en De Beer ontwikkel is, word daar verwys na sodanige opnames in die Hantam, in Calvinia se distrik, en die Kamiesberg in Namakwaland. Die praktiese implikasies van etnobotaniese studies word bespreek, en daar word spesifiek verwys na regsaspekte en intellektuele eiendomsreg. Daar word gekyk na die praktiese voordele en aanwending van etnobotaniese werk in (1) die kommersialisering van plantprodukte; (2) die bemagtiging van plaaslike gemeenskappe deur eko-toerisme; en (3) die rol van etnobotanie in skoolonderwys. Vervolgens word daar gekyk na die kulturele aanwending van etnobotanie, onder meer in (4) die skone kunste; (5) musiek; (6) kookkuns; (7) skryfkuns en poësie; (8) onomastiek (die oorsprong van plekname met die naam 'Hantam' as spesifieke voorbeeld). Laastens word die kollig geplaas op 'n gemarginaliseerde en dikwels afgeskeepte aspek van etnobotaniese navorsing, naamlik die magiese gebruike van toorplante.

The affordances of ethnobotanical research in the 21st century. Critics of ethnobotanical research may ask the question what the relevance is of documenting the indigenous knowledge of different cultural groups. This article focuses on the value and advantages of ethnobotanical research in the 21st century. The context is quantitative ethnobotanical surveys conducted in South Africa in recent years. For the discussion of the Matrix Method that was developed by Van Wyk and De Beer, reference is made to such surveys in the Hantam, Calvinia district in the Northern Cape, and the Kamiesberg in Namaqualand. The practical implications of ethnobotanical studies are discussed, specifically referring to legal aspects and issues of intellectual property rights. The affordances of ethnobotanical research are then considered, in (1) the development and commercialisation of products; (2) the empowerment of members of the community and the role of eco-tourism in socio-economic development, and (3) education. The cultural implications of ethnobotany is discussed next, such as found in (4) the arts, (5) music, (6) cuisine, (7) writing and poetry, (8) onomastics (the origin of place names - with the name 'Hantam' as specific example). Lastly, the focus is on a marginalised and often neglected aspect of ethnobotanical research, namely the magical uses of charm plants.

\section{Inleiding}

Etnobotanie word deur Balick en Cox (1996) beskryf as die studie van die verhoudings tussen mense en plante. Meer spesifiek, verwys dit na die kennis en vaardighede van mense in plaaslike gemeenskappe wat plante vir verskillende doeleindes gebruik. Outeurs soos Liengme (1983) en Van Wyk (2008) wys op die feit dat 'n groot deel van Suid-Afrikaanse inheemse kennis nie sistematies opgeskryf is nie (veral die inheemse kennis van Khoi- en Sanoorsprong), en omdat dit mondelinge tradisies is, dit die gevaar loop om vir ewig vir die nageslag verlore te gaan. Die afgelope paar jaar was daar wel ' $n$ beduidende oplewing van belangstelling in etnobotaniese studies, waarskynlik gedeeltelik aangevuur deur die Inheemse Plantgebruik-Forum (Indigenous Plant Use Forum, of IPUF). In Junie 2015 het IPUF sy 18de jaarlikse kongres gehou op Clanwilliam'n jaarlike hoogtepunt op die etnobotaniese kalender wat vanjaar in samewerking met die VSAgebaseerde internasionale Society for Economic Botany aangebied is (dit was hul 56ste jaarkongres). Hierdie forum het die afgelope paar jare 'n bydrae gemaak om veral swart studente te inspireer en bewus te maak van die inheemse kennis wat in die Suid-Afrikaanse flora opgesluit is.

Ongelukkig word etnobotanie dikwels gekritiseer dat dit onwetenskaplik en nie rigoristies is nie. Verdere kritiek is dat inheemse kennis oor plantgebruike irrelevant is in die 21ste eeuse 
samelewing en bloot as anakronistiese kuriositeite beskou behoort te word. 'n Algemene beskouing is dat die tradisionele gebruike van plante van weinige waarde is in 'n moderne, digitale wêreld wat deur kommersiële produkte in supermarkte, apteke en klinieke oorheers word.

Die doel van hierdie artikel is om eerstens te wys dat diepsinnige en rigoristiese etnobotaniese inligting ingewin kan word deur gebruik te maak van verbeeldingryke en toepaslike metodologie. In die tweede plek word die enorme werklike en potensiële impak wat inheemse kennis van plante inhou, uitgewys. Daar word gepoog om die vraag te beantwoord wat dikwels gevra word, naamlik: Wat is die doel en waarde van etnobotaniese studies?

\section{Die voordele van rigoristiese metodologie in etnobotaniese studies}

Die mees algemeen gebruikte metode vir ethnobotaniese opnames staan bekend as die Snelle Taksasie-metode ('Rapid Appraisal') (Martin 1995) en kan inderdaad gekritiseer word in soverre dit dikwels 'n lukrake en onvolledige insameling van feite is, wat nie onderwerp kan word aan statistiese analise nie. In die konteks van die opskrywing en bewaring van inheemse kennis is daar wel ruimte vir sodanige metodologieë indien tyd baie beperk is, maar as wetenskaplike metode laat dit veel te wense oor omdat dit nie die kwantifisering van data toelaat nie. 'n Wysiging, wat genoem word Deelnemende Landelike Taksasie ('Participatory Rural Appraisal') is ook al voorgestel (Martin 1995). 'n Kwantitatiewe benadering tot etnobotanie is vir die eerste keer deur Prance et al. (1987) voorgestel, maar is eers relatief onlangs vir die eerste keer in Suid-Afrika toegepas. Verskeie statistiese metodes is beskikbaar om gebruikspatrone uit te wys, o.m. die Kulturele Belange-Indeks ('Cultural Importance Index', CII) van Tardío en Pardo-de-Santayana (2008), die Indeks van Ooreenkoms van Rate ('Index of Agreement on Remedies, IAR) van Trotter en Logan (1986:91-112), asook hul Konsensusfaktor ('Consensus Factor', $F_{\mathrm{ic}}$ ) en ook die Getrouheidsvlak ('Fidelity Level', FL) van Friedman et al. (1986). Hierdie metodes word breedvoerig deur Heinrich et al. (2009) en Mutheeswaran et al. (2011) bespreek. Tydens 'n etnobotaniese studie in die Agter-Hantam (Figuur 1) het ons 'n eenvoudige nuwe benadering ontwikkel om vir die tekortkominge in bestaande metodes te vergoed. Aangesien die data met sodanige metode in die vorm van 'n matriks aangebied word en onderhewig is aan statistiese analisering, het ons dit die Matriksmetode genoem. Die besonderhede en voordele word sorgvuldig en breedvoerig uitgewys in 'n artikel in die Suid-Afrikaanse Tydskrif vir Plantkunde in 2011 (De Beer \& Van Wyk 2011a). Vir die doel van hierdie artikel word slegs enkele van die voordele kortliks uitgelig: geen valse negatiewe rekords nie (alle plantsoorte word aan alle deelnemers vertoon in die vorm van foto's en/of gedroogde plantmateriaal), geen beperking ten opsigte van seisoene en tyd van die jaar nie (foto's van blomme word buite seisoen gebruik), geen beperkende weersomstandighede nie (die werk word binnehuis gedoen), geen fisieke beperkings nie (die rykste kennis kom dikwels van senior burgers met beperkte mobiliteit en/of swak sig, wat ten volle kan deelneem) en die geleentheid om kennisvlakke binne die gemeenskap (en tussen gemeenskappe) te kwantifiseer (De Beer \& Van Wyk 2011a).

Die belangrikste voordeel van die Matriksmetode is dat dit navorsers in staat stel om die vlakke van inheemse kennis en die relatiewe belang van bruikbare plantsoorte te kwantifiseer op 'n lokale sowel as globale, direk vergelykbare skaal. Die metode word alreeds in Mexiko toegepas, waar skoolkinders in groepe blootgestel word aan die metode (dr. Kalina Bermúdez Torres, persoonlike mededeling). Sodoende word statistiese data bekom van die vlakke van etnobotaniese kennis in Mexiko, wat soos Suid-Afrika 'n brandpunt is van botaniese en kulturele diversiteit. Vervolgens word daar stilgestaan by die fundamentele rol van inheemse kennis oor plantgebruike in die huidige en toekomstige sosio-ekonomiese konteks van Suid-Afrika. Eerstens word praktiese implikasies uitgewys, waarna 'n bespreking van die kulturele implikasies van etnobotaniese studies volg.

\section{Praktiese implikasies van etnobotaniese studies Produkontwikkeling en wetgewing}

Twee stukke wetgewing is veral van belang in die konteks van inheemse kennis. Die eerste is die Wet op Biodiversiteit (Wet nr. 10 van 2004), gepubliseer in die Staatskoerant nr. 26436 van 07 Junie 2004 (tesame met die Regulasies, in Staatskoerant nr. 8831 van 08 Februarie 2008). Die onlangse Wysigingswet op Intellektuele Eiendomsreg (Wet nr. 28 van 2013), gepubliseer in die Staatskoerant nr. 37148 van 10 Desember 2013, het ook betrekking. Beide hierdie wette het ten doel om te verseker dat die houers van inheemse kennis die nodige beskerming teen uitbuiting geniet en dat hulle op 'n regverdige manier vergoed word vir die bydrae wat sodanige inheemse kennis lewer tot produkte en dienste. Hoewel hierdie wetgewing goed bedoel word, is daar fundamentele praktiese probleme met die toepassing daarvan. Enige etnobotaniese opnames wat in die plaaslike gemeenskap gedoen word, moet eerstens voorsiening maak vir etiese beginsels en tweedens moet dit die nodige erkenning gee aan plaaslike mense vir hul bydrae tot die kulturele erfenis van Suid-Afrika. Sodanige erkenning is ietwat problematies omdat die meeste van die inheemse kenners ongeletterd is en dus nie die volle impak van erkenning in 'n wetenskaplike artikel verstaan en waardeer nie. Die etnobotaniese opnames in die AgterHantam en Kamiesberg was hoogs sensitief vir hierdie oorwegings, en behels verskeie maatreëls om te verseker dat deelnemers op sinvolle en regverdige manier vergoed word vir hul deelname. Veral van belang, uit 'n regsoogpunt, is dat persoonlike erkenning gegee word aan alle anekdotes sodat die spesifieke oorsprong van inheemse kennis eksplisiet aangedui word in wetenskaplike artikels (byvoorbeeld ook in De Beer \& Van Wyk 2011a). Indien daar dus 'n dispuut sou ontstaan oor die houer(s) van inheemse kennis, verskaf 

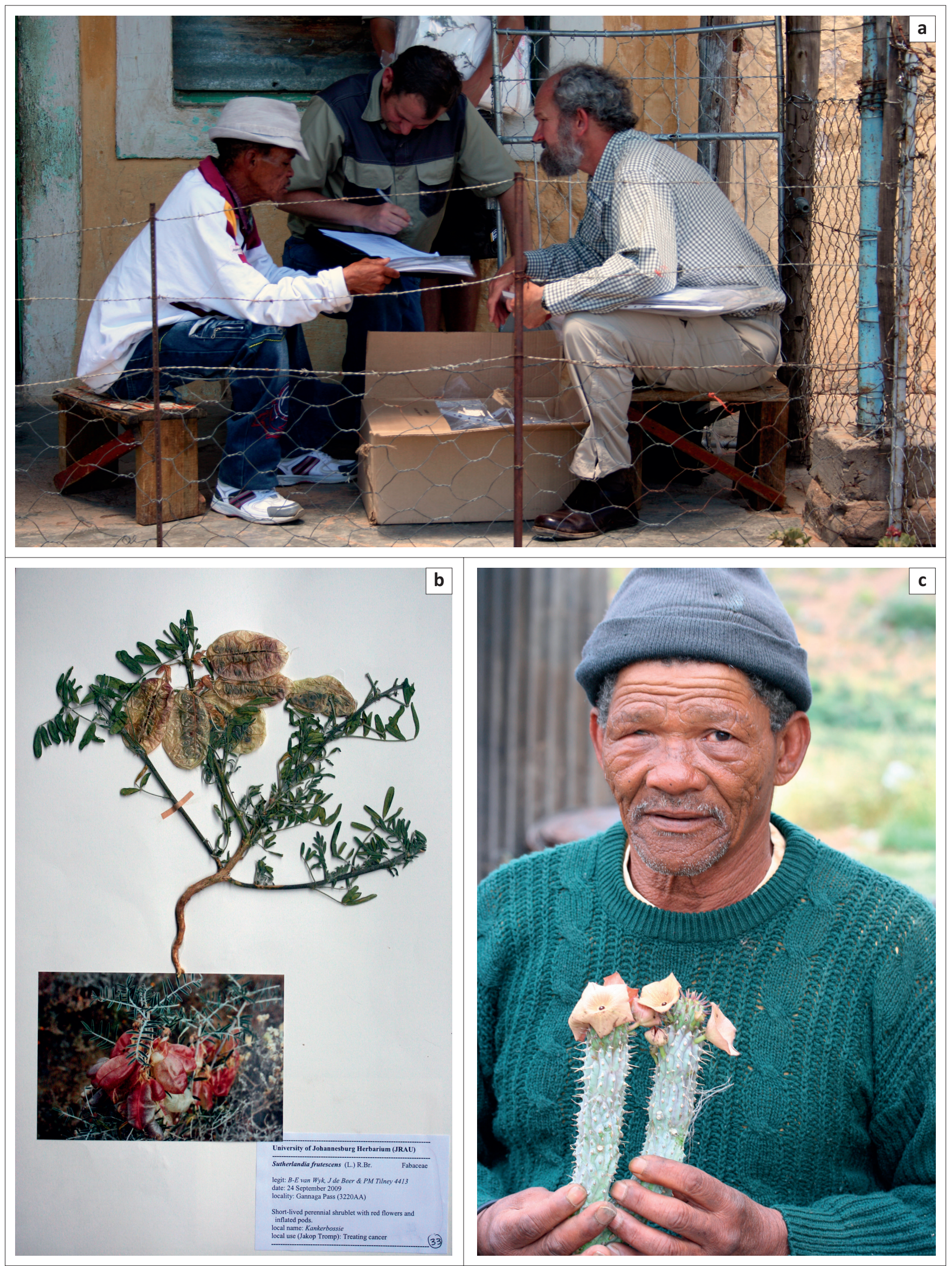

Bron: (a) P.M. Tilney; (b) J. de Beer; (c) B-E. van Wyk

FIGUUR 1: Etnobotaniese opnames in die Hantam, (a) Opnames met plaaslike mense; (b) Herbariumbewysstuk wat aan mense vertoon is (in hierdie geval, Sutherlandia frutescens; (c) Jan Baadjies, 'n plaaslike kenner van bruikbare plante, met blommende stingels van ghaap (Hoodia gordonii). 
die publikasies 'n onbetwisbare begindatum vir enige aansprake wat gemaak word. Hiermee word dus histories 'n vaste punt geskep vir die bronne van die inheemse kennis, en daarmee saam ook hopelik die nodige erkenning aan die dikwels ongeletterde intellektueles vir hul besondere ryke en inspirerende deelname aan navorsingsprojekte.

Een van die probleme met die toepassing van die biodiversiteitswet is die identifisering van die houers van kennis. Konsepwetgewing is waarskynlik gebaseer op die idee dat plaaslike gemeenskappe van mekaar geïsoleer is soos byvoorbeeld tipies wel die geval is in die Amasonewoude, en dat elke bepaalde gemeenskap dus unieke besit van hul eie intellektuele eiendom het. In Suider-Afrika kan hierdie beginsel moeilik toegepas word omdat grootskaalse historiese uitruiling van kennis tussen gemeenskappe en kultuurgroepe plaasgevind het, wat waarskynlik oor duisende jare strek. Die feit dat die meeste volksname van Kaapse plante vandag Afrikaans is, is ' $n$ duidelike demonstrasie van die grootskaalse uitruiling van kennis tussen die Khoi- en Saninwoners van die Kaap en die vroeë Europese setlaars. So is daar soortgelyke uitruiling tussen Xhosas en die Khoi in die Oos-Kaap, en selfs voorbeelde van interaksie tussen Sotho's en die San in Lesotho. Basothomense praat vandag nog van Athrixia-spesies as die 'boesman se tee', en in die Oos-Kaap word na Catha edulis verwys as boesmanstee. Die bekende Sanusi, tradisionele geneser Credo Mutwa, het in privaat gesprekke genoem dat intellektuele persone, dikwels die tradisionele helers (ook 'toordokters' of 'bossiedokters' genoem) gewoonlik na ander gebiede gereis het om meer inligting oor tradisionele medisyne te bekom, en ander kulture se medisinale plante te bestudeer. Dit is nie 'n ongewone praktyk nie, want hedendaagse akademici heg ook groot waarde aan internasionale reise, om op kongresse kennis uit te ruil en sodoende nuwe en meer globale perspektiewe te verkry. Waarom sal dit anders wees vir hoogs intelligente mense wat bloot nie kan lees of skryf nie, maar wat die rykdom van inheemse kennis in hul geheues vasgelê het? Die praktiese implikasie hiervan is dus dat geen enkele gemeenskap in Suid-Afrika noodwendig eienaarskap van bepaalde inheemse kennis kan opeis nie. In sommige gevalle, veral waar die plant se verspreiding hoogs gelokaliseerd is, kan daar dalk wel sprake wees van beperkte eienaarskap. 'n Oënskynlik goeie voorbeeld hiervan is dié van Sceletium of kougoed, die heel eerste Suid-Afrikaanse plant wat as potensiële medisinale gewas en bron van inkomste uitgewys is (Van der Stel 1685). Aangesien die sentrum vir die gebruik van hierdie plant in Namakwaland, en veral die Kamiesberg is, is een van die eerste voorbeelde van 'n ooreenkoms wat tussen 'n kommersiële maatskappy en 'n Khoi-gemeenskap gesluit is, dié van die ontwikkeling van Zembrin, wat tans ook in die VSA bemark word.

Dit is noemenswaardig dat dit die enigste plant is wat eksplisiet deur Van der Stel (1685) uitgewys is as een met besondere kommersiële potensiaal, om gekweek en verwerk te word as 'n nuwe produk. Wat egter maklik misgekyk kan word, is die feit dat Van der Stel aangeteken het dat Sceletium of kougoed, ook genoem kanna, deur die
Namakwas en omliggende stamme gebruik is. Die werklike benutting van kanna strek dus veel wyer as Namakwaland, en dit kom ook voor in die Klein- en Groot Karoo, met ander woorde die volle geografiese verspreidingsgebied van die genus Sceletium. Die alternatiewe naam vir die Klein Karoo, naamlik Kannaland, verwys trouens na dié plant. Hier is dus 'n werklike voorbeeld van die problematiek om intellektuele eiendomsreg toe te ken aan 'n bepaalde gemeenskap.

'n Tweede interessante voorbeeld van eksplisiete, historiese dokumentering van kosbare inheemse kennis, is dié van die bekende apteker en botanis, dr. Rudolph Marloth, skrywer van die eerste Flora van Suider-Afrika. As apteker het Marloth besondere belangstelling gehad in die medisinale gebruike van plante en het hy dikwels in sy Flora van vier volumes na die praktiese gebruike van die plante verwys (Marloth 1913-1932). In volume 3 van 1932 verwys Marloth spesifiek na die gebruik van Hoodia of ghaap (in hierdie geval Hoodia pilifera) om dors en honger te onderdruk. Hy skryf soos volg op bladsy 94 :

This is the real ghaap of the natives who use it as a substitute for food and water when both are scarce. The sweet sap reminds one of liquorice, and, when on one occasion thirst compelled me to follow the example of my hottentot guide, it saved further suffering and removed the pangs of hunger so efficiently that I could not eat anything for a day after having reached the camp.

Die heel eerste ooreenkoms tussen 'n kommersiële entiteit of agent (die WNNR) en 'n plaaslike gemeenskap, was die ontwikkeling van Hoodia as aptytonderdrukker (Wynberg 2010:127-140). Dit is 'n verdere voorbeeld van die problematiek geassosieer met die toekenning van regte aan 'n hoogs gelokaliseerde plaaslike gemeenskap, terwyl die gebruike en inheemse kennis van Hoodia oor 'n baie wyer area strek. Hierdie ooreenkoms met die Khomani San in die Kalahari kan dus bloot as 'n simboliese gebaar beskou word wat nie noodwendig verband hou met eiendomsreg nie. Die Sankultuur is veel ouer as dié van die Khoi en ander plaaslike kulture, en dus word daar skynbaar bloot aanvaar dat hulle die 'ontdekkers' moet wees van alle prakties bruikbare plante van Suider-Afrika. Dié aanname kan betwis word, aangesien die inheemse medisynesisteem verbasend dinamies is. Talle uitheemse plante (veral uit Europa en Suid-Amerika) word vandag gebruik as tradisionele medisyne en vorm tans deel van die Khoi-San se materia medica. Na die beste van my wete is daar geen direkte bewyse dat die Khomani San of enige ander San-gemeenskap die eerste gebruikers van Hoodia was nie. Die studie in die Agter-Hantam het aangetoon dat die aptytonderdrukkende effek van Hoodia bekend was aan die meeste plaaslike inwoners. Ek het trouens in my jeug as 'n 12-jarige seun eersterangs die hongerstillende effek van Hoodia gordonii in die Agter-Hantam ervaar, toe my gesette tante tydens 'n hele dagreis sonder kos of water, drie baie klein stukkies van die uiters bitter plant met groot entoesiasme verorber het.

Die beste strategie is waarskynlik om maatreëls in te stel wat die totale Khoi- en Sanbevolkings sal bevoordeel in gevalle waar gebruiksplante gekommersialiseer word. Dit 
lyk redelik en logies om aan te neem dat dit die Staat se verantwoordelikheid is om die inkomste wat uit belasting op suksesvolle, inheemse, kommersiële produkte bekom word, $o p$ 'n regverdige manier te versprei, en dus toe te sien dat arm gemeenskappe wie se kennis bygedra het tot die sukses van die produk op regverdige manier vergoed word. Sodanige maatreëls is waarskynlik reeds in plek, byvoorbeeld die bou van skole en klinieke in arm gemeenskappe, waar veel meer hulpbronne deur die Staat voorsien word as wat plaaslike gemeenskappe op sigself kan genereer.

'n Derde interessante voorbeeld is dié van rooirabas (Pelargonium sidoides) wat as hoogs suksesvolle bronchitismedisyne in Duitsland bemark word (en tans ook in ander lande). Die regsaspekte rondom dié en ander voorbeelde word breedvoerig deur Myburg (2011) bespreek. Soortgelyke beginsels, met die gepaardgaande gevaar dat onrealistiese verwagtinge geskep sal word, geld ook vir plante soos Sutherlandia, Aloe ferox, boegoe, rooibostee, heuningbostee, die peperbasboom, Afrikagemmer en wilde-als. Koorsbossie (Lippia javanica) is ook 'n interessante voorbeeld, wat gesamentlik deur inwoners van Giyani en die WNNR ontwikkel is as 'n effektiewe muskietafweerder.

Dit is nie net produkontwikkeling wat voordeel uit inheemse kennis trek nie. Daar is ook verskeie kulturele aktiwiteite en dienste wat op inheemse kennis gebaseer kan word, byvoorbeeld publikasies en boeke, gemeenskapsbemagtiging deur onderwys (skole), asook ekotoerisme, en verskeie ander minder ooglopende toepassings wat in die volgende afdeling in die kollig geplaas word.

\section{Ekotoerisme}

Suid-Afrika is wêreldbekend as 'n sentrum van botaniese en kulturele diversiteit. Gevolglik het akademici, en meer spesifiek etnobotaniste, die verantwoordelikheid om hierdie erfenis tot voordeel van toekomstige geslagte behoorlik te dokumenteer. Toerisme het vandag een van die leidende industrieë in die wêreld geword, en die aantrekkingskrag van bepaalde bestemmings hou direk verband met die biologiese en kulturele uniekheid wat daar ervaar kan word. Dit is duidelik dat die bevordering en toepassing van inheemse kennis, veral wat plante betref, ' $n$ fundamentele bydrae kan maak tot die sosio-ekonomiese opheffing van Suid-Afrika en die Afrika-kontinent as ' $n$ geheel, en dat dit in werklikheid die wese en gees van die konsep van die veelbesproke Afrika-Renaissance verteenwoordig. Die meeste van die produkte en dienste wat die moderne wêreld bied, was tot relatief onlangs slegs abstrakte moontlikhede (dink maar aan kernkrag, die rekenaar en die selfoon). Dit is dus moeilik om die volle impak van plante en die gebruike wat hulle in die toekoms moontlik kan hê, in hierdie stadium te visualiseer. Wat egter duidelik is, is dat ekotoerisme 'n toenemende bydrae tot werkskepping kan lewer. Die moderne toeris het gesofistikeerd geraak, en dus is dit lankal nie meer slegs olifante en leeus wat vandag die aantrekkingskrag vir buitelanse besoekers is nie. Japanse toeriste besoek Tafelberg byvoorbeeld in Januarie om die wonder van die Disa unifloraplant in volle glorie te aanskou. Europese toeriste, veral Duitsers, is intens geïnteresseerd in medisinale plante, omdat sulke plante ook 'n groot rol in hul eie kulture speel. 'n Groot deel van die onlangse sukses in die aalwynbedryf in Suid-Afrika is te danke aan die feit dat die sentrum van die bedryf - Albertinia in die Wes-Kaap - strategies geplaas is om die maksimum voordeel te trek uit toeriste wat reis op die Tuinroete tussen Kaapstad en Port Elizabeth (busse wat in die oggend uit Kaapstad vertrek, bereik Albertinia teen teetyd). Die potensiaal van inheemse kennis om te dien as toeristemateriaal wat deur talentvolle plaaslike kenners aangebied kan word, is onbeperk.

Tydens navorsing met' $n$ kundige deelnemer soos Jan Baadjies in die Agter-Hantam in Calvinia (Figuur 1) het die gedagte ontstaan dat hy ' $n$ besondere goeie toerleier kan wees in die ekotoerismebedryf, waar hy etnobotaniese uitstappies kan lei om mense bewus te maak van die veldkos en medisinale plante in Calvinia se distrik. Dit is 'n onontginde aspek van etnobotanie. In 'n land wat onder hoë werkloosheidsyfers gebuk gaan, kan etnobotaniese ekotoerisme baie individue bemagtig.

\section{Onderwys}

Etnobotaniese ondersoeke het reeds inslag gevind in die skoolkurrikulum. Die Kurrikulum- en Assesseringsbeleidverklaring in die natuurwetenskappe stel dit duidelik dat inheemse kennis in die klaskamer bevorder moet word. Onderwysers en onderwysowerhede benodig egter die kundigheid om dit te implementer, en hier kan etnobotaniese navorsing waardevol wees. De Beer en Van Wyk (2011b) het aangedui hoe etnobotaniese opnames met net die minimum apparaat in die Suid-Afrikaanse klaskamer gedoen kan word. Die afgelope drie jaar is kursusse ontwikkel om indiensopleiding te verskaf aan onderwysers oor hoe om sodanige etnobotaniese ondersoeke in hul klaskamers te fasiliteer.

\section{Kulturele implikasies van etnobotaniese opnames}

Die planterykdom van Suid-Afrika is een van die uniekhede van ons land wat groot potensiële voordele inhou en wat as 'n unieke verkoopargument vir die land beskou kan word. Genadendal in die Wes-Kaap is ' $n$ inspirerende, maar onderskatte sentrum van die Khoi se kulturele erfenis, tot so 'n mate dat president Nelson Mandela in 1995 die amptelike residensie van die president in Kaapstad van Westbrook na Genadendal herdoop het, as 'n huldeblyk aan die ryke en unieke nalatenskap van die Khoi. Dit is egter tragies om te sien dat die inheemse kennis van plante in hierdie sentrum agterweë gebly het, en dat daar tans skynbaar geen kenners is van die gebruike van tradisionele plante in die omgewing van Genadendal nie. 
Plante maak 'n bydrae tot talle fasette van kultuur. Hulle dien as inspirasie vir die kuns (beide skilderkuns en botaniese illustreerkuns), lirieke, ontwerpe, naamgewing (plekname), kookkuns, asook skryfkuns en poësie, om slegs 'n paar te noem.

\section{Skilderkuns}

Plante en blomme dien dikwels as inspirasie vir kunstenaars. Dit is veral in diebotaniese kuns datSuid-Afrika internasionale erkenning kry vir die gehalte van die werk van botaniese illustreerders. South African botanical art; peeling back the petals (Arnold 2001) verskaf 'n oorsig van die ryke tradisie van die botaniese illustreerkuns in Suid-Afrika. Pierneef se bome, en Maggie Laubser se aronskelke (varklelies) is enkele bekende voorbeelde van meer abstrakte uitbeeldings van plante in die skilderkuns.

\section{Lirieke}

Musiek is 'n belangrike aspek van kultuur, en plante soos waterblommetjies (Aponogeton distachyos) is byvoorbeeld verewig in die liedjie deur Anton Goosen met dieselfde naam. 'n Ander bekende voorbeeld is Coenie de Villiers se 'ruik jy katbos en kambroo, as dit reën in die Klein Karoo?'

\section{Kookkuns}

Figuur 2 toon enkele praktiese voorbeelde van die rol van plante in ons kookkuns, soos goewerneursboontjies (Phaseolus
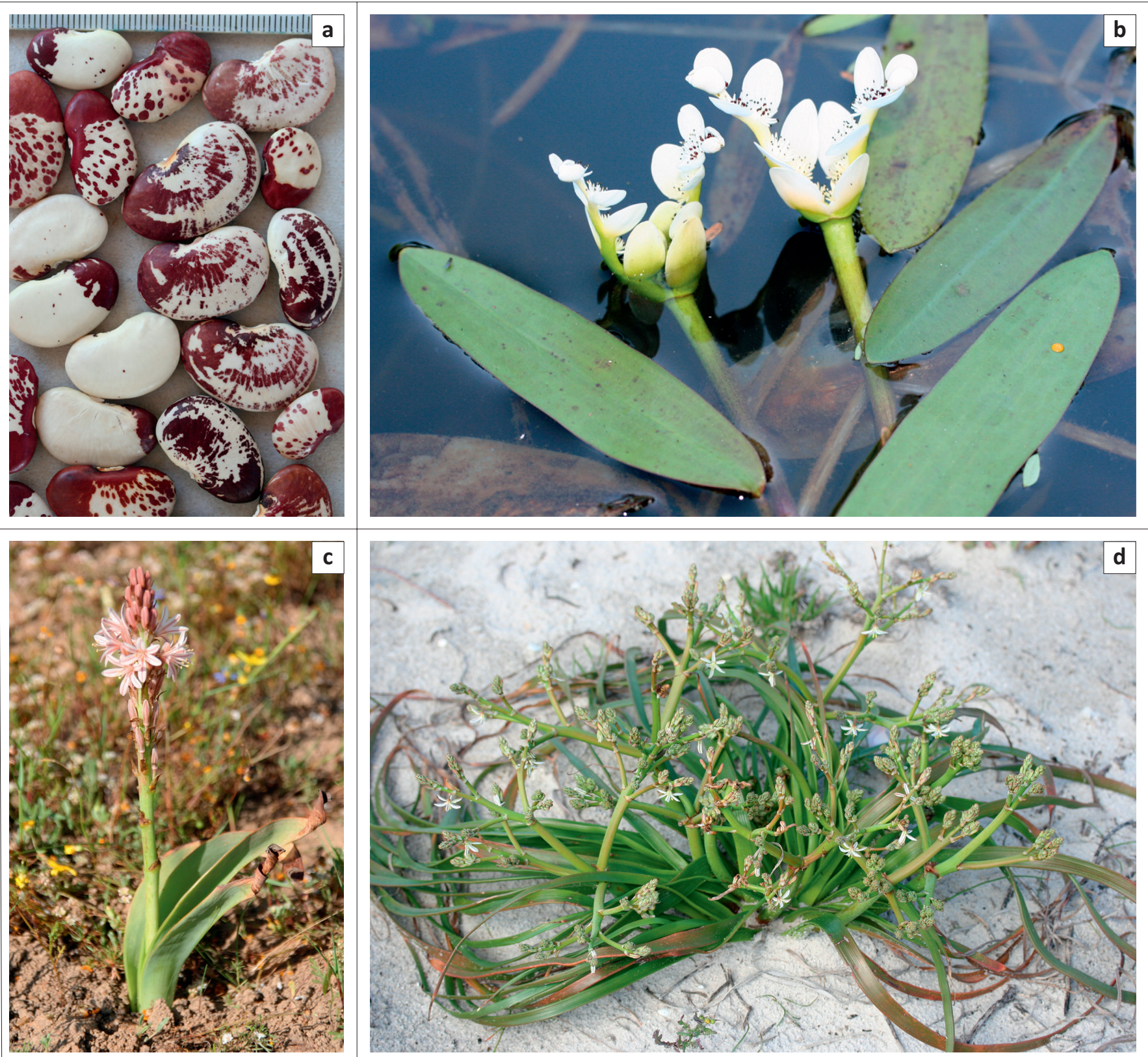

Bron: (a-f) B-E. van Wyk

FIGUUR 2: Voorbeelde van eg-Suid-Afrikaanse voedselplante: (a) Goewerneursboontjies (Phaseolus lunatus), volgens oorlewering ingevoer deur Simon van der Stel vanaf Suid-Amerika en sedert die 17de eeu in die Kaap verbou; (b) waterblommetjies (Aponogeton distachyos); (c en d) veldkool en duinekool (onderskeidelik Trachyandra falcata en Trachyandra divaricata); (e en f) Jakkalskos (die ondergrondse vrug van Hydnora africana). 

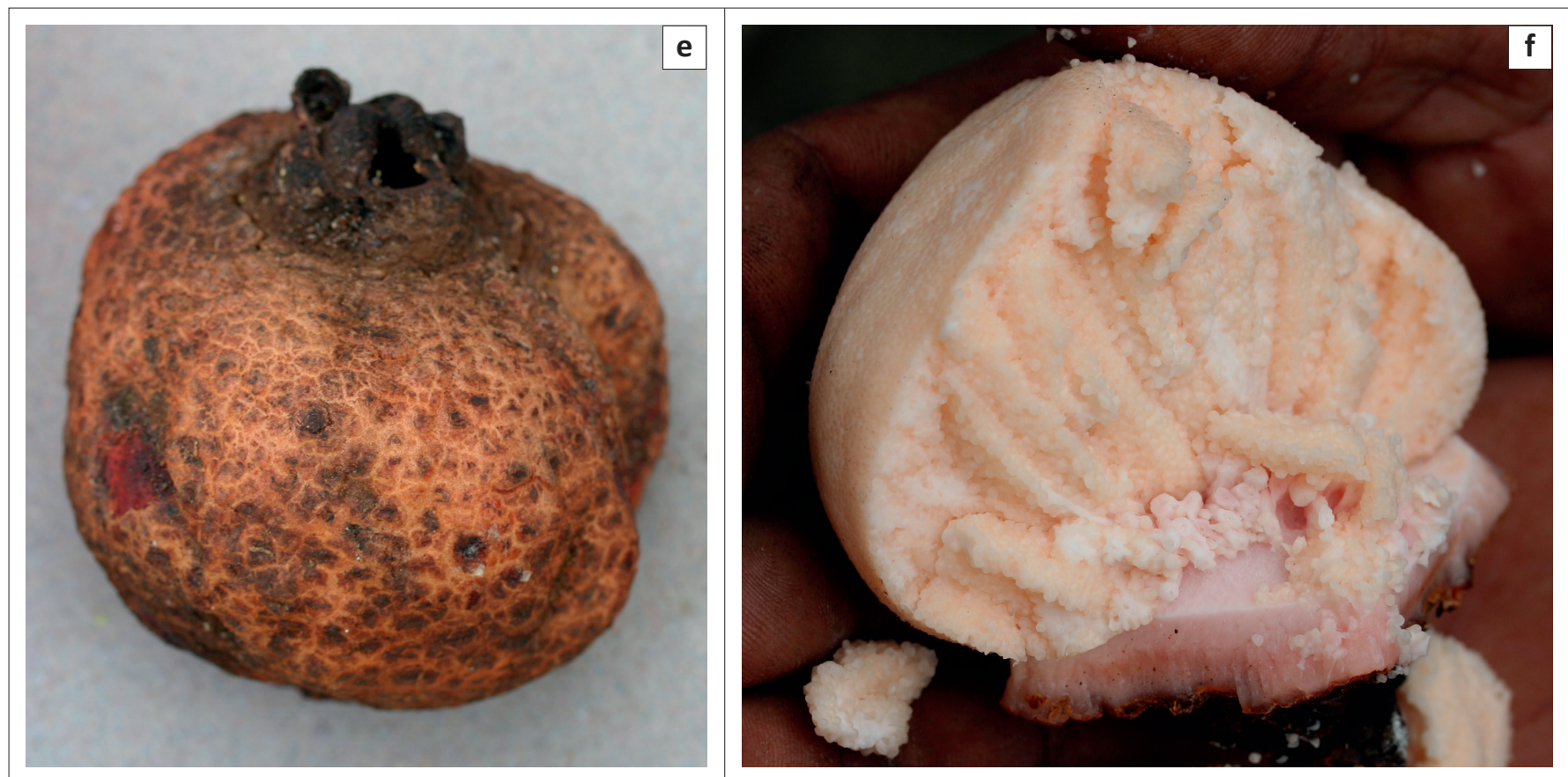

Bron: (a-f) B-E. van Wyk

FIGUUR 2 (Continues...): Voorbeelde van eg-Suid-Afrikaanse voedselplante: (a) Goewerneursboontjies (Phaseolus /unatus), volgens oorlewering ingevoer deur Simon van der Stel vanaf Suid-Amerika en sedert die 17de eeu in die Kaap verbou; (b) waterblommetjies (Aponogeton distachyos); (c en d) veldkool en duinekool (onderskeidelik Trachyandra falcata en Trachyandra divaricata); (e en f) Jakkalskos (die ondergrondse vrug van Hydnora africana).

lunatus), wat tot vandag toe aan die Kaapse Weskus verbou word, waterblommetjiebredie (Aponogeton distachyos), veldkool en duinekool (onderskeidelik Trachyandra falcata en Trachyandra divaricata) en Leipoldt se jakkalskos-soufflé (Hydnora africana) (Leipoldt 1976, 1978; Rood 1994; Van Wyk 2011; Van Wyk en Gericke 2000). Betsie Rood (1994) se boek Uit die veldkombuis, en die onlangse boek van Renata Coetzee en Volker Miros (2009), getiteld Koekemakranka: KhoiKhoin kultuurgoed en kom-kuier-kos is voorbeelde van 'n nuwe bewuswording van die enorme potensiaal om inheemse plante in die kookkuns op te neem en in spesialisrestaurante aan toeriste te bied as 'n unieke Suid-Afrikaanse ervaring.

\section{Skryfkuns en poësie}

Een van die mees treffende voorbeelde van die gebruik van plante in die skryfkuns is sekerlik dié van Boerneef (die skuilnaam van die digter I. W. van der Merwe, 1897-1967). Hier is 'n bekende voorbeeld, 'n gedig uit Palissadryne (Boerneef 1977):

Ek wil 'n ruik kan ruik as ek koffiewater kook

soos tkoiinghoutkole of anosterbosrook. (bl. 51)

Daar word verwys na die renosterbos (Elytropappus rhinocerotis) as brandhout en sy kenmerkende reuk, wat deur sommige kenners as 'n essensiële geurkomponent van roosterkoek beskou word. Tkoiinghout verwys na die stamme (stompies) van dooie karoobossies (soos renosterbos) wat as brandhout benut word. Hierdie digter besing in sy digkuns talle plante, o.m. boegoe, ghaap, kambro, perslyn, pypsteelbos, geelbossies, kattekruie, aandblom, botterboom, santolien, waboom, sederhout, suikerbossie, ghwarriebos, melkbos, appelliepie (=appelliefie), spaansriet, koekmakrank, vinkel, jakkalskos, gousblom, kokerboom, ganna, doringboom, kraalbos, vygie en suurvy. Plante vorm ook'n belangrike deel van Marlene van Niekerk se digkuns. In Sprokkelster (Van Niekerk 1977) lees ons o.m. van suikerkanne, keurtjiebos, kruidjie-roer-my-nie, koekmakranke, kapokbos, kiesieblaar, wildemosterd, waterblommetjie, gousblom, pietsnot, spekbos, kanniedood, seeroogblom, twa, gannabos, seeboon, bergrose, wilde-anys, salie, boegoe, jantjiebêrend, klokkiesheide, tjienkerientjee, fluitjiesriet en skaapbossie. Die bome en houtsoorte van die Knysnabosse speel 'n belangrike rol in Dalene Matthee (1984) se bekende boek Kringe in ' $n$ bos, met verwysings na onder meer stinkhout, kalander, assegaai, ysterhout en saffraan.

\section{Onomastiek: Plekname en die oorsprong van die naam 'Hantam'}

Etnobotaniese veldopnames kan ook 'n bydrae maak om die oorsprong van plekname verder te ontrafel. Khorixas in Namibië is, byvoorbeeld, die Damaranaam vir Salvadora persica, die relatief skaars mosterdboom, wat volop in die rivier by die dorp voorkom en plaaslik as medisyne benut word.

Volgens Nienaber (1971:233) is 'Hantam' 'n Afrikaanse vervorming van 'n Hottentotse samestelling !Hanłami wat 'rooiuintjiesberg' beteken. Aldus Nienaber was dit oorspronklik die naam van 'n bergreeks, wes van Gibeon. Later is die naam Hantam ook gegee aan die bergreeks in die distrik Calvinia. Du Plessis (1973) verwys na Pettman se afleiding dat Hantam gebaseer is op 'n verwysing van J.E. Alexander na 'n berg: 
From Tuais we saw the long line of the Un'uma, or Bulb Mountain, two or three thousand feet high, east of us. [Van Tuais kon ons die lang lyn van die Un'uma, of Bolberg, twee of drie duisend voet hoog, oos van ons sien.] (p. 100, [author's own translation])

Unúma en Hantam is volgens hierdie outeur 'n poging om die Hottentotwoord !han $\neq$ ami (!hani, Wachendorfia sp. en !homi, 'n berg; dus 'red veld bulb mountain' voor te stel. Nienaber sê uitdruklik dat hierdie interpretasie verkeerd is. Volgens hom kan dié afleiding nie na aanleiding van Alexander se Un'uma gemaak word nie.

Smith (1966) noem die plantnaam heyntame wat in Simon van der Stel se joernaal voorkom. Dit verwys na die bolplant Pelargonium bifolium, en aldus Smith is dit die naam waarvan Hantam afgelei is, want Pettman se Wachendorfia sp. (rooiwortel) kom nie daar voor nie, maar eerder verskeie Pelargonium-soorte met kenmerkende bloedrooi wortels of stingels, soos o.m. Pelargonium antidysentericum. Nienaber en Raper (1983) verbind die naam Hantam ook aan die heyntamewortel, Pelargonium bifolium.

Die name aree (vir Pelargonium carnosum) en wilde aree (vir $P$. antidysentericum) wat tydens die opnames in die AgterHantam vir die eerste keer sedert 1685 aangeteken is, is dus van besonderse betekenis in die naspeuring van die oorsprong van die naam Hantam. Die enigste oorspronklike literatuurverwysing na aree is in die 'Dagh Register' van Simon van der Stel se Namakwalandse ekspedisie (Van der Stel 1685), waar dit gelys word as die Griekwanaam vir twee spesies van Pelargonium (die Nama-ekwivalent is Heyntame). Hiervolgens sou Smith (1966) se voorstel dus daarop neerkom dat die naam Hantam afgelei is van Pelargonium antidysentericum en ander Pelargonium-soorte wat algemeen voorkom in die omgewing rondom die Hantamberg. Die logiese afleiding is dat Heyntame of Heyntam en aree onderskeidelik die Nama (khoekhwoegowab) en generiese Griekwa-name is vir die genus (geslag) Pelargonium (die Afrikaanse ekwivalent is malva of wilde-malva) (Figuur 3).

Raper, Möller en Du Plessis (2014), wys egter daarop dat die pleknaam nooit as Heyntam aangegee is nie, maar altyd as 'Hantam'. Volgens hierdie outeurs is daar 'n nuwe en meer waarskynlike verklaring vir die naam 'Hantam', gebaseer op ouer literatuur wat daarop dui dat 'Hantam' en 'Vaderlandsche Rietfontein' sinonieme is. Laasgenoemde is skynbaar 'n etimologiese aanpassing van die Khoikhoi-naam vir vaderlandsriet (Phragmites communis), naamlik Han-ta of han- $\neq a$, saamgestel uit die Khoikhoi-woorde han (='vaders', aangeteken in 1752) en $t^{\prime} a$ of $\neq a\left(==^{\prime}\right.$ riet'$^{\prime}$, aangeteken in 1801).

\section{Magiese gebruike van plante (paljas en toorplante)}

'n Uitsonderlike en raaiselagtige aspek van inheemse plantgebruik en inheemse kultuur is die benutting of toepassing van plante wat nie maklik wetenskaplik verklaar kan word nie. Bygelowe en metafisiese rituele vorm deel van die kulture en literatuurerfenisse van die meeste lande ter wêreld, maar Suid-Afrika is waarskynlik uniek omdat die magiese gebruik van plante in die verlede aktief onderdruk is (Die Bekamping van Heksery, Wet van 1957, wat voortspruit uit vroeër wetgewing van 1895 [Ashforth 2005]). Dit was deel van 'n algemene patroon van kulturele meerderwaardigheid van die polities dominante kultuurgroep. So byvoorbeeld is toegang tot klinieke verbied wanneer dit aan die lig gekom het dat tradisionele medisyne gebruik is. 'n Wanbegrip van die oënskynlik irrasionele gebruik van plante het gelei tot konsepte soos 'toordokter' en 'heksery', en die gedagte dat sulke twyfelagtige praktyke onderdruk moet word. Daar is talle voorbeelde van die gebruik van plante wat op die oog af onwetenskaplik en metafisies voorkom, maar wat by nadere ondersoek verbasende nuwe insig gee in die kultuur van mense wat nie kon lees of skryf nie, en wat nie toegang gehad het tot moderne tegnologie soos die mikroskoop nie.

Die manier waarop uitdrukking gegee is aan konsepte soos kieme ('bose geeste') en koors ('die toestand van die voël') is sprekende voorbeelde van die misverstand wat kan ontstaan tussen die reduksionistiese Westerse beskouing, en die meer holistiese en metafisiese beskouing van ongeletterde mense wat tot onlangs nog totaal aangewese was op natuurprodukte vir hul oorlewing, en wat nie die tegniese insig gehad het om dramatiese natuurverskynsels op 'n rasionele manier te verklaar nie (meer hieroor later in hierdie afdeling). Daar is ook 'n sterk element van psigologiese behandelings wat deel uitmaak van 'n holistiese genesingskultuur: talle plante word dus gebruik, nie as chemiese entiteite met 'n biochemiese werking nie, maar as demonstrasies en rituele wat dien om bepaalde emosionele en/of spirituele doelwitte te bereik. 'n Interessante voorbeeld is die opstandingsplant (Myrothamnus flabellifolius). In Zoeloe word dit 'Uvukwabafile' genoem, en volgens Credo Mutwa is die plant tradisioneel gebruik as teenvoeter vir rou, en om die trauma van verlies aan die dood te behandel, asook ernstige depressie. Die plant is relatief onbekend, omdat dit slegs in gelokaliseerde rotsagtige plekke voorkom. 'n Tradisionele geneser kan daarop reken dat die pasiënt waarskynlik nie met dié plant en sy besondere eienskappe vertroud sal wees nie. Die opstandingsplant verleen sy naam aan die unieke vermoë om in die droë wintermaande op te krul en bruin te word sodat dit lyk asof dit doodgegaan het. Die blare aan so'n oënskynlik dooie takkie kan egter binne enkele ure wonderbaarlik oopvou en verkleur tot heldergroen nadat dit in water geplaas is. Die naïewe wetenskaplike sal hom dadelik na die laboratorium haas om die chemiese bestanddele te isoleer wat vir die antidepressante werking verantwoordelik is. Die tradisionele gebruik het egter niks met biochemie te doen nie. Die tradisionele geneser gee 'n takkie van die plant aan die persoon in rou, met die opdrag om dit in 'n glas water op 'n vensterbank te plaas en die volgende dag te rapporteer wat gebeur het. Die heler sal dan aan die pasiënt verduidelik dat daar altyd hoop is, en dat lewe na die dood nie onmoontlik is nie, soos wat die oënskynlik dooie takkie gedemonstreer het. Hier is dus 'n voorbeeld van 'n sielkundige behandeling, wat maklik verkeerd geïnterpreteer kan word, veral deur mense wat nie vertroud is met die fyner besonderhede van die Zoeloes se geneeskunde nie. 

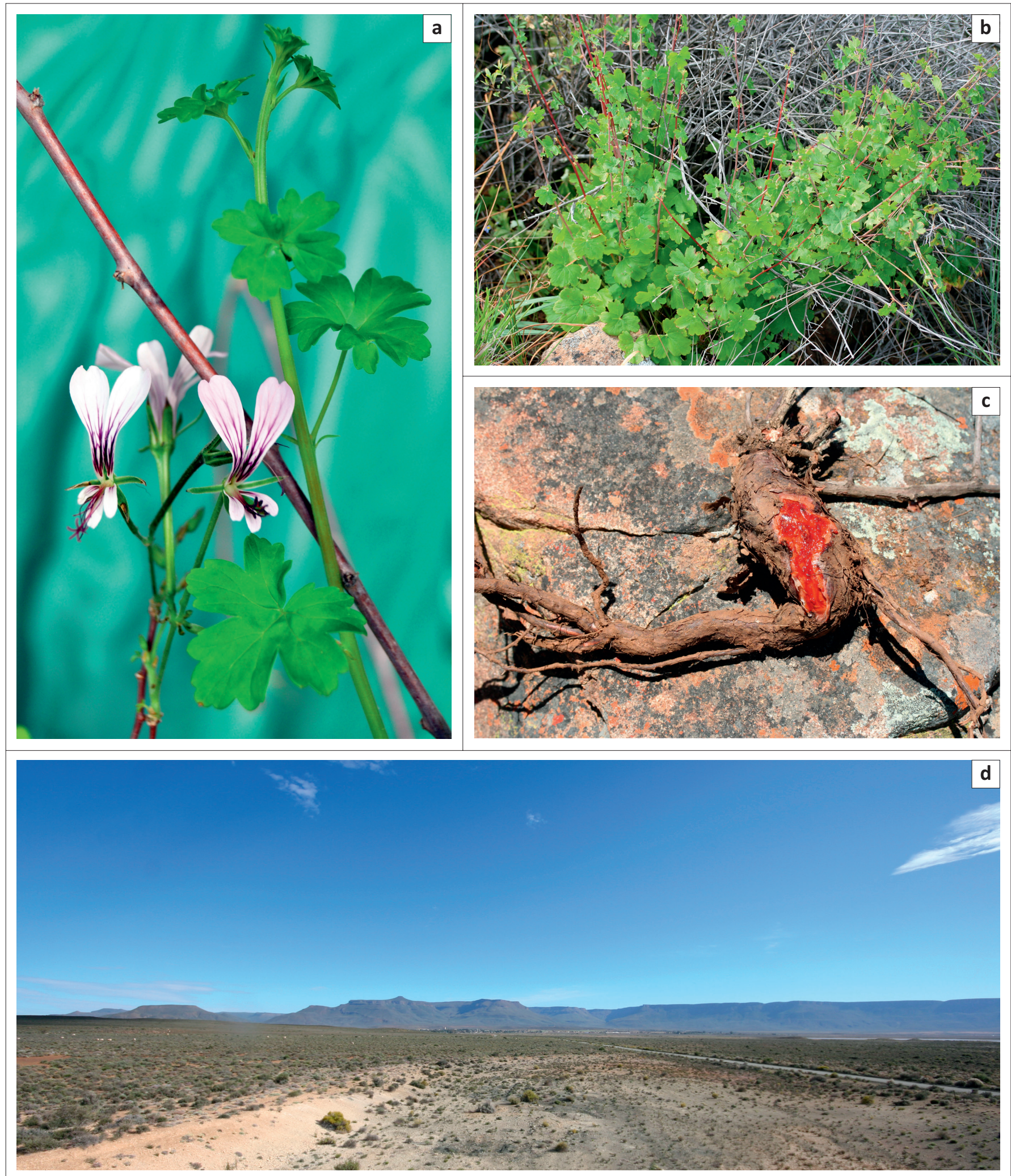

Bron: (a-d) B-E. van Wyk

FIGUUR 3: Pelargonium antidysentericum (Eckl. and Zeyh.) Kostel. (Geraniaceae): (a) Blare en blomme van Pelargonium antidysentericum; (b) blare van Pelargonium antidysentericum; (c) wortel van Pelargonium antidysentericum; (d) die Hantamberg.

Vroeër is die voorbeeld van kieme en bose geeste genoem, wat nou verder belig word. Verwysings na 'bose geeste' (byvoorbeeld in die huis) sal waarskynlik onmiddellik met agterdog bejeen word deur 'n Westerse persoon wat geen ervaring van inheemse kultuur het nie. Bose geeste in ' $n$ huis

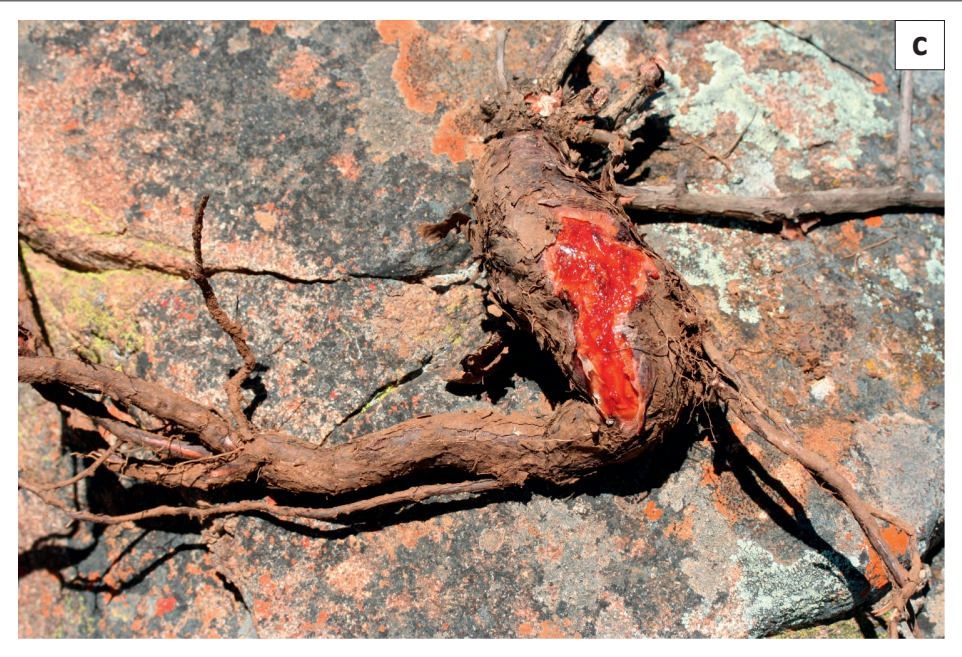


tradisioneel teen bose geeste gebruik. 'n Treffende voorbeeld is 'impinda' of slangklimop (Adenia gummifera), 'n dodelik giftige rankplant waarvan die stamme vryelik op tradisionele markte verkoop word. 'n Afkooksel van die kenmerkende heldergroen stamme word tradisioneel in en om die huis gesprinkel om bose geeste te onderdruk. Vandag gebruik ons bleikmiddels en antiseptiese kommersiële produkte vir dieselfde doel, naamlik om skadelike mikroörganismes te bekamp.

Vervolgens meer inligting oor koors, en die metafoor van die voël, waarna vroeër verwys is: ' $n$ Merkwaardige voorbeeld van Afrika-mitologie is aangeteken tydens 'n besoek aan die sentrale Kalahari. Hierdie verhaal word vertel in Van Wyk en Gericke (2000), asook in Dugmore en Van Wyk (2008), en word kortliks hier herhaal om die belang van mitologie in 'n niegeletterde samelewing te demonstreer. Die storie van die skaduwee van die blouvalkie behels die gebruik van die Kalahari-koorsbossie (Dicoma schinzii) om die toestand (siekte van die skaduwee van die blouvalkie) te genees. Daar is gesê dat as die skaduwee van die blouvalkie op 'n baba val, die baba siek sal word, en dat hierdie siekte maklik herken word aan die spastiese rukbewegings van die arms van die baba, soortgelyk aan die fladdering van die vlerke van die blouvalkie wanneer hy oor sy prooi hang. Daar is verder gesê dat wanneer die toestand onbehandeld bly, babas dalk vere kan ontwikkel op hul arms. 'n Aftreksel van die plant word beide uitwendig en inwendig toegedien, en sal die simptome teenwerk en genesing bewerkstellig. Die diepsinnigheid van die storie het eers duidelik geword toe dit blyk dat die persoon die tradisionele behandeling van koorsstuipe in babas beskryf. Die simbool van die voël verteenwoordig koors, omdat voëls 'n hoër natuurlike liggaamstemperatuur van gemiddeld $40{ }^{\circ} \mathrm{C}$ het, teenoor die $37^{\circ} \mathrm{C}$ by die mens. Dit het later geblyk dat 'die toestand van die voël' ook onder ander Afrika-kulture na koors verwys. Die verwysing na vere op die arms wat op die oog af totaal irrasioneel voorkom, het egter sy ekwivalent in ander kulture ook (in Afrikaans verwys ons na hoendervleis; in Engels 'the gooseflesh offever') een van die simptome van stuipe in babas. Wat die storie nog interessanter maak, is die ongelooflike mnemoniese waarde wat dit moet hê vir 'n persoon wat gereeld in kontak met blouvalkies kom. Elke keer wanneer die blouvalkie sy opwagting maak, word almal herinner aan die gevaar dat die skaduwee van die voël op die baba kan val, en sodoende word die behandeling van stuipe by babas, oor en oor in die geheue verfris. Dit is interessant dat al die belangrike feite van die behandeling in die vorm van 'n storie verweef is, wat nie maklik vergeet sal word deur mense wat nie die voordele van literatuur of argiewe het nie.

In die ondersoek in die Hantam was dit opvallend hoe Jan Baadjies, 'n persoon wat die plante van die streek en die medisinale waarde daarvan baie goed ken, dikwels na die paljasgebruike van plante verwys het. In 'n onderhoud het hy byvoorbeeld verwys na interessante metafisiese manifestasies, byvoorbeeld hoe Kaatjie Hoesaar, die Sanvrou by wie hy sy opleiding ontvang het, in 'n leeu kon verander het. Low (2004) verwys daarna dat die Ju/'hoan, / num of /Gais tradisioneel gesien word as die ' $\mathrm{krag}^{\prime}$ binne-in die tradisionele geneser. Hierdie /num of /Gais gee aan die geneser sekere vermoëns - in hierdie geval die transformasie tot 'n leeu, alhoewel daar nie vasgestel kon word of Jan dit metafories bedoel het nie. Jan Baadjies kan dalk na die intense 'energievloei' of $n / u m$, soos bespreek deur Lee (1967) verwys het, of na Marshall se interpretasie van $n / u m$ as 'toormedisyne', of 'n 'vlug' (soos aangehaal deur Low 2004). Low (2004:178) verwys na Köhler (1963) wat opgemerk het dat in die Khoi- en Sankulture diere (byvoorbeeld leeus) gesien word as die vermoë om mense te toor met tçó, wat beteken om 'siek te maak'. Jan Baadjies kan dus verwys het na Kaatjie Hoesaar se vermoë om paljas te gebruik om mense siek te maak.

Nog 'n baie interessante bevinding tydens etnobotaniese opnames, beide in die Agter-Hantam (De Beer \& Van Wyk 2011a) en in die Kamiesberg in Namakwaland (Nortjé \& Van Wyk 2015) was die vele verwysings na 'die waterslang'. In die literatuur is daar ook velerlei verwysings na die waterslang, soos die volgende aanhaling uit Von Wielligh (1921):

The large Watersnake carries a beautiful shiny gemstone on her head. At a great distance, the gleam of this gemstone can be seen, and it shimmers with exceptional light rays that far exceed the light of the Moon; because it can clearly be seen at noon on the brightest sunshiny day. [Die groot Waterslang dra 'n pragtige, glinsterende halfedelsteen op haar kop. Die glans kan van'n groot afstand gesien word, en dit skyn met ligstrale wat helderder is as die strale van die maan, want dit kan selfs in die middag op ' $n$ baie helder dag gesien word.] (p. 75, [author's own translation])

\section{Samevatting}

Etnobotanie as 'n vakgebied is met rasse skrede aan die groei, en die ontwikkeling van die rigoristiese en stipte Matriksmetode vir sodanige ondersoeke, hou die voordeel in dat die patrone van plantgebruike in verskillende gebiede en selfs wêrelddele direk met mekaar vergelyk kan word. Tydens die studie in die Hantam, kon die oorsprong van die gebied se naam herlei word na die plant Pelargonium antidysentericum (en verwante soorte). Die bydrae wat etnobotaniese studies kan lewer tot die onomastiek is nog nie behoorlik ontgin nie, hoewel talle plekname hul oorsprong by plantname het. Omdat inheemse kennis mondeling oorgedra word, kan etnobotaniese studies verseker dat hierdie kennis in die vorm van publikasies en boeke vir toekomstige nageslagte bewaar word. Verder hou etnobotaniese navorsing ook die moontlikheid in om kommersiële plante te identifiseer wat ' $n$ potensiële bron van inkomste vir mense kan wees indien die ontwikkelingsproses 'n sukses sou wees. Etnobotaniese ekotoerisme hou ook baie belofte in. Die insluiting van tradisionele kennis oor die gebruik van plante in die skoolkurrikulum kan baie bydra om inheemse kennis in Suid-Afrika te bevorder en om mense trots en bewus te maak van die diepsinnige waarde van wat gewoonlik as alledaagse en onbelangrike feite beskou word. Etnobotaniese inligting vind ook neerslag in die kunste en selfs in kookkuns. Die relevansie daarvan om tradisionele inligting op te teken, en die waarde daarvan in die 21ste eeu, kan in die lig van 
bogenoemde argumente inderdaad as vanselfsprekend beskou word maar hopelik gee hierdie oorsig 'n beter begrip van die omvang en diepte van inheemse etnobotaniese kennis.

\section{Erkenning Mededingende belange}

Die outeur verklaar dat hy geen finansiële of persoonlike verhouding(s) het wat hom op 'n positiewe of negatiewe wyse by die skryf van die artikel kon beïnvloed het nie.

\section{Literatuurverwysings}

Arnold, M. (ed.), 2001, South African botanical art: Peeling back the petals, Fernwood Press, Vlaeberg.

Ashforth, A., 2005, 'Muthi, medicine and witchcraft: Regulating African science in post-Apartheid South Africa', Social Dynamics 31(2), 211-242.

Balick, M.J. \& Cox, P.A., 1996, Plants, people and culture: The science of ethnobotany, Scientific American Library, New York.

Boerneef (Van der Merwe, I.W.), 1977, Versamelde poësie, Tafelberg-Uitgewers, Kaapstad.

Coetzee, R. \& Miros, V., 2009, Koekemakranka; Khoi-Khoin kultuurgoed en kom-kuierkos, Lapa Uitgewers, Kaapstad.

De Beer, J. \& Van Wyk, B-E., 2011a, 'An ethnobotanical survey of the Agter-Hantam, Northern Cape Province, South Africa', South African Journal of Botany 77, 741754. http://dx.doi.org/10.1016/j.sajb.2011.03.013

De Beer, J. \& Van Wyk, B-E., 2011b, 'Doing an ethnobotanical survey in the Life Sciences classroom', The American Biology Teacher 73(2), 90-97. http://dx.doi. org/10.1525/abt.2011.73.2.7

Dugmore, H. \& Van Wyk, B-E., 2008, Muti en mites uit Afrika, Marula Books, Pretoria.

Du Plessis, E.J., 1973, 'n Ondersoek na die oorsprong en betekenis van Suid-Afrikaanse berg-en riviername, Tafelberg-Uitgewers, Kaapstad.

Friedman, J., Yaniv, Z., Dafni, A. \& Palewitch, D., 1986, 'A preliminary classification of the healing potential of medicinal plants, based on a rational analysis of an ethnopharmacological field survey among Bedouins in the Negev Desert, Israel', Journal of Ethnopharmacology 16, 275-287. PMID: 3747566, http://dx.doi. org/10.1016/0378-8741(86)90094-2

Heinrich, M., Edwards, S., Moerman, D.E. \& Leonti, M., 2009, 'Ethnopharmacological field studies: A critical assessment of their conceptual basis and methods', Journal of Ethnopharmacology 124, 1-17. http://dx.doi.org/10.1016/j.jep.2009.03.043

Köhler, O., 1963, 'Observations on the central Khoisan language group', Journal of African Languages 2, 227-234.

Lee, R.B., 1967, 'Trance cure of the! Kung Bushman', Natural History 76(9), 31-37.

Leipoldt, C.L., 1976, Leipoldt's Cape cookery, W.J. Flesch and Partners, Kaapstad. Leipoldt, C.L., 1978, Kos vir die kenner, 2de uitgawe, Tafelberg-Uitgewers, Kaapstad.

Liengme, C.A., 1983, 'A survey of ethnobotanical research in southern Africa', Bothalia $14,621-629$.
Low, C., 2004, 'Khoisan healing: Understandings, ideas and practices', unpublished D.Phil thesis, Christ Church, University of Oxford, Oxford.

Marloth, R., 1913-1932, The flora of South Africa, 4 vols., Darter, Kaapstad and William Wesley, London.

Martin, G., 1995, Ethnobotany, Chapman \& Hall, London.

Matthee, D., 1984, Kringe in ' $n$ bos, Tafelberg-Uitgewers, Kaapstad.

Mutheeswaran, S., Pandikumar, P., Chellappandian, M. \& Ignacimuthu, S., 2011 'Documentation and quantitative analysis of the local knowledge on medicinal plants among traditional Siddha healers in Virudhunagar district of Tamil Nadu, India', Journal of Ethnopharmacology 137, 523-533. PMID: 21718779, http:// dx.doi.org/10.1016/j.jep.2011.06.003

Myburg, A.F., 2011, 'Legal developments in the protection of plant-related traditional knowledge: An intellectual property lawyer's perspective of the international and South African legal framework', South African Journal of Botany 77(4), 844-849. $\mathrm{http}: / /$ dx.doi.org/10.1016/j.sajb.2011.09.003

Nienaber, P.J., 1971, Pleknaamwoordeboek (Deel 1), Tafelberg-Uitgewers, Kaapstad.

Nienaber, G.S. \& Raper, P.E., 1983, Hottentot (Khoekhoen) place names, Human Sciences Research Council, Pretoria.

Nortjé, J.M. \& Van Wyk, B-E., 2015, 'Medicinal plants of the Kamiesberg, Namaqualand, South Africa', Journal of Ethnopharmacology 171, 205-222. PMID: 25944008 , http://dx.doi.org/10.1016/j.jep.2015.04.049

Prance, G.T., Balee, W., Boom, B.M. \& Carneiro, R.L., 1987, 'Quantitative ethnobotany and the case for conservation in Amazonia', Conservation Biology 1(4), 296-310. http://dx.doi.org/10.1111/j.1523-1739.1987.tb00050.x

Raper, P.E., Möller, L.A. \& Du Plessis, L.T., 2014, Dictionary of Southern African place names, Jonathan Ball Publishers, Johannesburg.

Rood, B., 1994, Kos uit die veldkombuis, Tafelberg-Uitgewers, Kaapstad.

Smith, C.A., 1966, Common names of South African plants, Botanical Survey Memoir No. 35, Department of Agricultural Technical Services, Pretoria.

Tardío, J. \& Pardo-de-Santayana, M., 2008, 'Cultural importance indices: A comparative analysis based on the useful plants of Southern Cantabria (Northern Spain)', Economic Botany 62(1), 24-39. http://dx.doi.org/10.1007/s12231-007-9004-5

Trotter, R.T. \& Logan, M.H., 1986, 'Informant consensus: A new approach for identifying potentially effective medicinal plants', in N.L. Etkin (ed.), Plants in indigenous medicine and diet, biobehavioural approaches, Redgrave Publishers, Bedford Hills, NY.

Van der Stel, S., 1685, 'Simon van der Stel's journey to Namaqualand in 1685', in G.C. de Wet \& R.H. Pheiffer (eds.), 1979, facsimilee edition, Human \& Rosseau, Kaapstad.

Van Niekerk, M., 1977, Sprokkelster, Human \& Rousseau, Kaapstad en Pretoria.

Van Wyk, B-E., 2008, 'A review of Khoi-San and Cape Dutch medical ethnobotany', Journal of Ethnopharmacology 119, 331-341. PMID: 18703129, http://dx.doi org/10.1016/j.jep.2008.07.021

Van Wyk, B-E., 2011, 'The potential of South African plants in the development of new food and beverage products', South African Journal of Botany 77, 857-868. http:// dx.doi.org/10.1016/j.sajb.2011.08.003

Van Wyk, B.E. \& Gericke, N., 2000, People's plants: A guide to useful plants of Southern Africa, Briza Publikasies, Pretoria.

Von Wielligh, G.R., 1921, Boesman-Stories. Deel 1: Mitologie en legendes, 2de uitgawe, De Nationale Pers, Kaapstad.

Wynberg, R., 2010, 'Policies for sharing benefits from Hoodia', in R. Wynberg, D. Schroeder \& R. Chennells (eds.), Indigenous peoples, consent and benefit sharing: Lessons from the San-Hoodia Case, Springer, New York. 